November - 2005

\title{
The Online Learning Environment: Creating a space for Mauritian women learners
}

\author{
Sushita Gokool-Ramdoo \\ Tertiary Education Commission, Mauritius
}

\begin{abstract}
This paper examines how online distance education acts to democratize access to, and suit the ontologies of, Mauritian women who seek to empower themselves for development. Data from semi-structured interviews of 30 middle class couples are presented in this paper. Interviews and analyses are premised on a feminist perspective and conducted within the social relations analysis framework. The objective of this research was to understand what types of supportive environments (social spaces) enable Mauritian women to engage in educational endeavours that promote their personal potentials and creativities which, in turn, advance democracy for all citizens of Mauritius. Husbands were also interviewed to provide ground for analysis and to decrease bias, which can be generated by women-only data. 1) Marriage/ family and 2) occupation, represent the 'social spaces' selected for this study. Discretion, degree of learner control, and the outreach capacity inherent in distance learning makes the online modality a natural choice to democratize women's access to education. Based on interviewees' experiences and perceptions, this study concludes that online learning can enhance and democratize women's access to education for personal development - but only if the power relationships in the two 'social spaces' are well understood and well negotiated by these women. The findings in this paper shed light on the importance of understanding 'learner spaces' when establishing and setting-up open learning organisations.
\end{abstract}

\section{Introduction}

This paper analyzes the extent to which online distance learning works to democratize access to education for women learners in Mauritius; it also underlines the importance of providing a supportive environment to sustain women learners throughout their educational endeavours. Investigated are the interpersonal relationships of women learners in two 'social spaces:' (1) family/ marriage and (2) occupation. Explored are interpersonal relationships that can provide support - or become obstacles - toward women's attainment of education. Also presented are strategies (i.e., as based on evidence gathered that reveal the hidden obstacles faced by women learners) that should ideally be woven into the developmental plan of any future open learning organisation in Mauritius.

\section{Purpose}

The purpose of this research is to determine how two social spaces, 1) family/ marriage and 2) occupation enable or impede women's access and participation in educational opportunities via online distance learning. In short, the aim of this research is to uncover the degree to which these 
'social spaces' can impede or empower women; it does so by exploring the interrelationship between distance education, occupation, and personal development. Put simply, the goal of the author is to advance the process of democratizing access for women learners in Mauritius, and does so by discovering via semi-structured interviews 'what social situations' impede or support women learners. The findings from this study support the call for course design strategies that address the specificities of women as distance learners in Mauritius; the findings also contribute to the literature on the field of women and distance education, specifically by providing a voice to women learners living in a developing country.

For this paper, 'democratizing access' means enlarging and enhancing possibilities of women learners to register and participate in an educational program; that is, examining how online education can be designed to suit the ontologies of Mauritian women to empower them for development. 'Democratizing access' is a functional definition that can be found in the UNESCO definition of 'democracy,' which stipulates that democracy is a dynamic state that offers a 'space' for individual voices. This 'space' encourages peace rather than conflict (UNESCO, 2001, p.25). The state of 'continuing peace' is an important concept within this conceptual framework; moreover, 'continuing peace' helps us to rethink the concept of 'development' as being premised on the notion of 'human dignity' as a central supportive element (UNESCO, 2001, p.25). In line with this re-conceptualization of 'development,' it is necessary to promote the development of 'human creativities' that aim to eliminate individual frustration. Indeed, from this conceptualization, 'frustration' is a major source of conflict, and thus a threat to democracy. As part of lifelong learning, 'personal development' is seen to be achievable through educational endeavours that are aimed at various levels of interventions and phases, and that are delivered through different modalities. Thus the link between education, personal development, national development, and democracy is well established. However, without placing emphasis on building viable 'social spaces' that provide access to education, it is impossible to realize the type of development necessary to foster 'human dignity' and nurture 'human creativity.' Because distance education offers tremendous access, particularly to marginal or oppressed groups seeking to negotiate and overcome impeding power relationships, the online educational modality may also be seen within the context of democracy.

\section{Online Distance Education and Mauritian Learners}

Rumble argues that Internet-based education "would meet the pressure from students for convenience-education by delivering programs into their homes" (Rumble, 2001, p. 5). In Mauritius, state-sponsored provision of online distance education is not yet existent, however. The good news is that this situation is starting to change. As of 2003, just over 40 percent of Mauritians reported owning personal computers (Week-end, 2003). In addition, several incentives are in place for sustainable provision of online distance education: the Development Bank of Mauritius is now offering low-interest loans to those individuals seeking to purchase a personal computer; Mauritius Telecom now provides affordable broadband packages; a growing number of (free of cost) computer courses are available to larger cross sections of Mauritius' population; and finally, the Government of Mauritius is seeking to make e-learning more widely available, particularly through the creation of a new open learning organisation.

This study is premised on several assumptions. First, it is premised on the assumption that online education offers women wider access to more varied combinations of education. This study is also premised on the assumption that women must balance multiple 'social roles' as adult learners. It is from these dual assumptions - 'social roles' versus 'student roles' - that the interaction between online distance education and Mauritian women learners is examined. 
Self-directed learning (Brockett and Hiemstra, 1991; Chang, 2003; Garrison, 2003) and constructive learning experiences that contribute to critical thinking in terms of learning to learn, (Moore and Kearsley, 1996), result in paradigm shifts which, in turn, act to catalyze personal development. In this study, the purpose is to understand how meaningfully online distance education can advance the 'democratization' of access for potential women learners in Mauritius.

This paper comprises three sections: 1) literature review; 2) overview of the research method and research process; and 3) a summary of the research findings, with particular emphasis paid to the possible application of the research findings aimed to guide the policies of a newly announced open learning organisation in Mauritius (Government of Mauritius, Budget Speech, 2004).

\section{Part I: Literature Review}

\section{The Issue of Women's Access to Education}

For the past two decades, particularly since the Jomtien Conference on Education for All (1990), the subject of educational access (especially women-related) has gained increased attention on the problems in terms access to education. Indeed, the subject of educational access has been gaining increased attention, ranging from the classical-liberal economic approach of the World Bank, to the human rights approach of agencies as the United Nations Development Program (UNDP) and the United Nations Children Fund (UNICEF). Many reasons can explain exactly why women in particular lack of access to education. In lesser developed parts of the world, like the sub-Saharan Africa for example, insufficient infrastructure, transport facilities, distance to schools, security problems, religious and cultural beliefs, economic constraints, and armed conflicts, are all major factors that impede women's (and others') access to education. Conversely, in the developed world, research indicates that impeding factors are subtly integrated in variables such as sexist curricula, sexist bias in classes, lower self-esteem of girls, and teacher's lower expectations (Stanworth, 1981).

It is within this context that distance education has often been seen as a potential solution to help advance the lot of women. May (1994), for example, argues that it is important to consider the feminist ramifications of distance education in order to enhance the understanding of women. This view is echoed by Kramarae (2003) and Henri (1989), and particular attention has been paid to women's socio-cultural and economic environments by the scholars Kirkup and von Prümmer (1990). The fact that more than a decade separates Kirkup and von Prümmer's views (1990) from Kramarae's (2003) indicates, however, that this topic is still in need of thorough investigation and remains extremely relevant to contemporary scholars researching the field of distance education and feminism.

Indeed, it was the paucity of research on middle-class women that spurred the researcher's interest to explore the reality faced by women learners in her native country, Mauritius. According to the literature, one's class position reflects his or her market situation (Haralambos, 1984). For example, the middle class women who participated in this study were all in a position to potentially better their life. Yet as Liddle and Joshi (1986) point out "the vast majority of educated middle-class women are still confined to domestic activities” (p. 55), which, for some women, can be truly oppressive. This means that 'social terms' pertaining to the nature and ownership of 'housework' for example, need to be redefined and re-negotiated. This study attempts to uncover the extent in which middle-class Mauritian women were redefining such 'terms' to make which their overall environment/ social spaces more enabling. 


\section{Part II: Research Framework}

\section{Standpoint Feminism}

The feminist perspective, which has informed the basis for this study, is a "lens through which to view the process of inquiry and its social, historical, and political context" (Fonow and Cook, 1991, p.1-2). Among the various feminist research frameworks available - and despite the difficulty it may cause for over generalisation - this author opted for 'standpoint feminism' to form the basis of this research study. Some feminists (Harding, 1987; Hartsock, 1990; Ramazanoglu, 1993) advocate standpoint feminism as the best approach to investigate and understand women's lived reality. From this perspective, women researchers are bound to produce knowledge about women that is “more complete and less distorted than [does a] man's experience" (Harding, 1987, p.95). Moreover, while standpoint feminism accepts the basic premise of scientific endeavour, its knowledge is derived from a committed feminist exploration of women's oppression (Fonow and Cook, 1991). The standpoint feminism perspective acknowledges the researcher's bias, and requires that researcher explain the analytic process of her research (Harding, 1987; Hartsock, 1990; Ramazanoglu, 1993). However, standpoint feminism presents a threatened external validity. While there is no doubt about the internal validity of the data generated, critics of standpoint feminism could argue that the external validity of this perspective could be threatened because of the avowed subjective nature of its investigations and the inherent difficulty in replicating such studies.

\section{Social Relations Analysis Framework}

The researcher used the standpoint feminism perspective grounded within the 'social relations analysis framework.' The social relations analysis framework seeks to understand the social processes that sustain unequal power distributions. "Making power relationships the focus of analysis highlights the differences among women, and draws attention to factors other than gender through which groups have access to resources such as communities" (Heward and Bunwaree, 1999, p. 3). This framework helps to unveil the precise terms under which women and men cooperate, and examine the specific institutions such as marriage and markets, that structure such cooperation.

\section{The Spaces Under Study: marriage/ family and occupation}

Two social spaces were analyzed in this study: 1) marriage/ family and 2) occupation, and both were found to be 'social spaces' rife with power struggles. May (1994), for instance, argues that while cultural sensitivities must be considered, historical patriarchal structures also need to be thoroughly questioned and modified accordingly.

\section{Marriage/ Family}

Because they were the most private spaces in which married women operated, for the purpose of this study the opinions and viewpoints of both husbands and wives were sought, and family/ marriage as discrete institutions were merged together.

Heward and Bunwaree (1999) argue that marriage and cohabitation bind many women into unequal power relationships with men. According to these scholars, inequality is not intrinsic to relations between men and women, but is linked to wider social and economic structures. It is claimed that the institution of marriage itself holds significant influence on the welfare of women 
and the status of men (Heward and Bunwaree, 1999). O'Connell (1994) explored the contradictions for women that are inherent in the family; she argues that while for many women 'family' is a place of security and support, it may also be an instrument of oppression, subordination, and brutality. Thus, it becomes necessary for researchers to ascertain the extent to which the husband, in particular, and the wider kinship in general, are supportive of women.

\section{Occupation}

Occupation represents the most public sphere wherein women construct meaningful experiences and relationships. In addition to advancing their material circumstances, employment can hold transformative potentials for women in terms of advancing and enhancing their self-worth and social potential. Heward and Bunwaree (1999) for instance, argue that women's access to education has improved the status of women within the family, in that education has acted to reduced family size, and it has expanded women's economic roles. This study, therefore, seeks to determine whether the relationship between distance education and occupation is similarly reinforcing; whether occupation can provide an 'empowering space' wherein women have both the time and facilities to study; and whether women acquire the skills they need for upward social mobility. Indeed, Bullock (1994, p. 89) recognized that women require a range of vocational, entrepreneurial, and managerial skills to positively transform their professional situation. In concurring with Heward and Bunwaree (1999), Bullock also concludes that the relationship between education, employment, and empowerment remains inherently complex.

\section{Distance Education and Women}

Education can enable women to discover, explore, and expand upon their hidden potential(s). Unless women have control over resources, however, education cannot be a guarantor of capitalizing on one's potentials. While education may not better women's general condition, it does place them at a decisive fulcrum which allows them to make more informed choices for personal development. The specific relationship between distance education and women is murky, however. While women stand as adult learners in their own right, the fact that they are 'women' gives them a specificity that must be thoroughly examined on its own terms. May (1994) for example, asserts that although women generally praise distance education, they also unanimously agree that "it isn't for everyone" and that it is a significantly different experience for female learners than male learners (May, 1994, p. 1). This reinforces the need to study women in terms of patriarchal-defined parameters.

Most distance learners are adults between the ages of 25 and 50 (Moore and Kearsley, 1986). Moreover, the attrition rate among these adult distance learners is a matter of concern, which has resulted in calls for research that aims to "to understand what causes some students to withdraw, in the hope of being able to improve their completion rates" (Moore and Kearsley, 1986, p. 153).

Such research has been undertaken. Kemp (2002) for example, argues that personal characteristics such as motivation, self-efficacy, personality, attitude, and maturation combined with life circumstances and transitions, are predictors of attrition. The degree to which women are affected by such predictors can determine their successful completion of any distance learning course. May's (1994) findings, however, suggest that the actual control women exercise over their study schedules appears to be over-stated in the literature. Nonetheless, the women in May's study also claimed that access to, and use of, communication technologies for educational purposes (despite their imperfections) allowed them to juggle home-study with their busy schedules. She concluded, however, that further research remains warranted to improve women's distance study experiences (May, 1994). 
On the other hand, Kemp (2002) research shows that students' work and/ or occupational obligations were found to impede the successful completion of their studies. In short, Kemp determined that personal 'life events' were not found to be a causative factor in learner persistence in general, but instead one's inability to strike a workable balance between marriage family/ occupation found to be strongly negative factor leading to student attrition. Kramarae (2003) furthers this line of research by stressing importance of ensuring that "past sexist practices, which have been a problem on most campuses, are not perpetuated online” (p. 261) an issue that arguably remains both timely and valid over a decade later.

Online distance learning offers opportunities for collaborative learning, while at the same time enables learners to study at a time and place convenient to them. The Web allows for asynchronous (and increasingly synchronous) interpersonal communication, and facilitates learning between instructors and students, and collaboration among learners using email, bulletin boards, and online discussion forums. Web-based learning, however, should be meaningful, contextualised, and purposeful (Brown, 1997) for it to make a difference. The difference being that a fundamental distinction must be made between opening access to education for greater numbers of students and opening access that fosters and enables 'human development.' Indeed, opined here is that while there is merit in widening access to education, there maybe little real benefit in increasing the numbers of enrolees without a concomitant increase in viable employment opportunities. Hence, the need to exercise caution in developing distance education programs and establishing open learning organisations, versus what opportunities are really/ socially available to graduates.

\section{The Research Context}

The Mauritian population consists of 65 percent Indo Mauritians; 30 percent Afro-Mauritians; three percent Sino-Mauritians; and two percent Franco-Mauritians (Parsuramen, 1994). Supported by a research grant from the Mauritius Research Council, this study is based on qualitative research data gathered from 30 middle class couples of Indo Mauritian background. It was convenience sampling that dictated this selection. The nature of the research and the type of investigation involved made it difficult to include participants from other backgrounds because of their lack of willingness to reveal personal details.

Mauritius gained Independence from British rule in March 1968. And while primary schooling has been free in Mauritius since 1976, regardless of gender, secondary education has also been free. Therefore, because education in Mauritius is free it could be logically assumed that an increasing number of females should have benefited from the apparent educational opportunities available at the primary, secondary, and tertiary levels. Moreover, it could logically be assumed that access to free education should also have translated into women's increased participation in various skilled and professional occupations throughout Mauritius. Theoretically, expansion in the occupational economic structure should be reflected in educated women as part of the labour force. In reality, however, the number of females who reached tertiary education is considerably lower than that of males, especially considering that more young females than young males entered secondary education in Mauritius.

The figures in Table 1, derived from data produced by the Tertiary Education Commission Mauritius, shows that in 2003 female enrolment at public school secondary level in Mauritius stood at 51.9 percent compared to male enrolment of 48.09 percent. This data can be compared to tertiary level enrolment, which reveals that female entrants to the University of Mauritius drops to only 46 percent compared to 53.47 percent for males (TEC, 2003), a pattern of disparity that has persisted for the last 20 years. Gender-based data for students studying abroad or with private 
educational institutions in Mauritius is not yet available and thus prevents a more complete picture from emerging at this time.

Table 1. Total Enrolment Rates by Gender and Level in Thousands for Year 2003

\begin{tabular}{lll}
\hline & Secondary Level (\%) & $\begin{array}{l}\text { Tertiary Level } \\
\text { (University of Mauritius only) }\end{array}$ \\
Males & 49.946 & 3.072 \\
Females & 53.901 & 2.673 \\
\hline
\end{tabular}

During the course of this research study, steps were taken to identify the barriers Mauritian women typically face in their journey towards educational attainment. Based the findings of women's 'lived circumstances,' the use of online distance education as a delivery modality was analysed and found to be justified for this target group of learners. Thus, it is assumed here that strategies of inclusiveness for women learners in Mauritius tertiary educational system would contribute towards the democratic tradition of the country.

\section{Research Methods}

The type of information gathered from potential women learners in Mauritius covered the following broad areas, and eventually provided the guidelines for the formulation of the research questions:

1. How did the current education level of the subjects determine their awareness of the importance of personal development and related opportunities?

2. How did the subjects define 'personal development' and did they relate it to national development?

3. Given their familial responsibilities and professional commitments, how did subjects view online distance education as a means for personal development?

4. Is the 'marriage/ family sphere' an 'enabling space' for personal development? And what is the role of online distance education in that space?

5. Is the professional environment an 'enabling space' for personal development? And what is the role of online distance education in that space?

6. Did online distance education have a democratizing influence on access, as we tend to believe?

Thirty married couples $(n=30)$ comprised of working Indo Mauritian women and their husbands were interviewed to provide answers to the above. The questions posed to the husbands pertained mostly to their awareness of 'personal development' and the importance they attributed to this concept, as well as their contribution towards 'personal development.' To determine the research methods that would best answer these questions, the author used a method that springs from feminist theory.

The preferred method for this research study was the semi-structured interview. This approach allowed the researcher flexibility to allow respondents to ask questions if they felt they needed 
clarification. The questions were "tailored to fit the respondents' knowledge, degree of involvement and status" (Guba and Lincoln, 1983, p.186).

\section{Sampling}

This study was based on convenience sampling. The majority of respondents were personal acquaintances of the researcher. Willingness to cooperate for this research was proportional to the researcher's closeness to the individuals, especially male spouses. This group was selected because of their financial and infrastructural ability to engage in online learning. The researcher had originally hoped to interview 100 couples, but ended up with only 30 couples.

To provide a more complete picture of how women lived and benefited from within their respective 'social spaces,' their husbands were also interviewed. This approach to data collection aimed to minimise the polarization between men and women, a situation that tends to happen inadvertently in feminist studies. Along with providing a firmer ground for analysis, this approach thus decreased the bias that may be generated by women-only data (Harding, 1987). It is believed that this would improve the internal validity of data finally obtained. Table 2 provides the breakdown of interviewees by age-group.

Table 2. Interviewees by Age-group

\begin{tabular}{lcc}
\hline Age Group & Number of Women & Women Respondents (\%) \\
20-30 years old & 16 & 53.3 \\
$30-40$ years old & 9 & 30 \\
$40-50$ years old & 2 & 10 \\
$50-60$ years old & 2 & 6.7 \\
\hline
\end{tabular}

The majority of women interviewees $(n=16)$ were from the 20-30 age group, while only two ( $n$ $=2$ ) were from the 40-50 age group, and two $(n=2)$ from the 50-60 age groups. When interviewed, the husbands did not always volunteer personal information (i.e., age) so it was impossible to capture their age-groups in this study. Despite being more aware of possibilities and opportunities open to them, many of the younger women reported to having less space for decision-taking and action in their households, which were often watched over by their mothersin-law. On the other hand, the older women reported that old age had shaken the stronghold of their mothers-in-law. This gave the older women in the study more 'space to breathe,' but they were sadly aware that a lot of time had gone by and there were many things in their lives that they would simply not have the chance to experience.

Class distinction in Mauritius should be mentioned at this point to provide contextual background for this study. Class distinction in Mauritius is inherently complex due to the interplay of ownership of property, level of income, and to some extent, ethnic variables. In the preIndependence era, which was dominated by slavery (slaves from Africa and Madagascar) and indentured labour (labourers from India and China), the notion of class based on wealth, especially in terms of property, was concentrated in the hands of the French and British colonials. That concentrated wealth was eroded, however, when indentured Indian labourers were given marginal land to cultivate in lieu of salary (thus becoming wealthy property-owners); and indentured Chinese labourers were given opportunity to become traders (thus forming a wealthy business community). In the post-Independence era, much of the above status was retained with the only difference being a newly emerging middle-class comprised of franchised slaves and labourers (especially the educated), who started earning an income. To focus this study, class distinctions will only comprise level of income derived from employment based within the Indo- 
Maurtitian community. For ease of discussion, the researcher has not taken into consideration any other form of wealth.

Only eight of the Indo Mauritian women interviewed were from the lower-middle and 12 from the middle classes. Two from the upper-middle class were interviewed engaged in an online distance learning pursuit. All women were registered in graduate or under-graduate distance education programs. At the time of this study, all wives and husbands were engaged in full-time employment.

\section{The Research Process}

Underlying this research process was an awareness of power relationships - that is the researcher was aware of her power to activate and influence the research process; thus, like a mastermind, the researcher calculated for ways to elicit responses from some of her research subjects, specifically the reluctant husbands. The researcher achieved this by acknowledging husbands' worries, placating their egos, while at the same time empathising with the women.

The researcher met with all the wives and, in some instances, the couples in their own homes. When faced with reluctant husbands, however, the researcher found herself confronted with the necessity of devising a strategy to extract information. Empowered by the literature from feminist studies that describe the used of non-conventional data collection methods (Chant and Mc Ilwaine, 1998), the researcher resorted to an alternative tactic to gather the much needed data she asked the wives of the reluctant husbands to interview their husbands themselves. Thus the researcher coached these wives to give their husband's a brief description of the research study. The purpose of this description was to solicit their husbands' participation. Of the 30 husbands interviewed, the researcher personally interviewed only eight. Data from the other 12 were gathered by the wives on her behalf. Ten husbands declined participation and informed the researcher that they did not want to disclose information/ details about their private spheres. In the face of this anticipated obstacle to data collection, it is opined that the husbands' interviews conducted by the wives still constitute an important source of information. Albeit imperfect, based on the results and quality of the data collected, the data can be used to inform future research.

\section{Limitations}

While this research study gained its strength from the documentation of various experiences, its major limitations were the lack of ethnic representation of the research population; the reluctance of some husband participants; and the un-anticipated method used to extract participation from some male subjects. In other words, without further research designed to validate this study's findings, readers are cautioned on the generalisability of the data collected and any inferences drawn. Despite this, however, enough information was gathered to formulate a coherent conclusion to this study.

\section{Part III: Research Findings and Possible Applications}

The strategy used was designed to enable women learners to participate more effectively in their 'social spaces.' Understanding women's roles and power structures is important in developing distance learning courses and programs of study. Based on the research findings, the analysis offered here is based on a feminist perspective. Indeed, researchers cannot eschew the business of studying from real life, nor can they ignore the power relationships that characterise spaces where 
real life is enacted. Power relationships must therefore be thoroughly examined, understood, and inherent power relationships recognized and redressed. To help redress the current imbalance between female and male learners, a feminist approach should permeate any policy informing an open learning organisation in Mauritius.

\section{Understanding Marriage/ Family and Occupation}

From the data gathered, marriage and occupation for the middle-class women interviewed seemed to offer enough 'space' to foster personal development via participation in online distance educational activities. All women interviewed indicated that they were happier married than not married. In the Mauritian cultural context, marriage provides 'space' for personality growth and development that is typically not available in other personal contexts like bachelorhood and spinsterhood. Living together in relationships other than marriage (i.e., out of wed-lock) is not socially acceptable and thus frowned upon by Mauritian society.

All women interviewed were engaged in full-time employment. Subjects from the lower middle classes were engaged in employment activities, typically as administrative staff working for public and private organisations. The other groups were engaged in professions ranging from middle to upper management in public and private organisations. Occupation, therefore, provided a vital 'space' for personality development and hence, for increasing women's predisposition to participate in democracy. The views expressed by husbands also provided further insights in addition to those of the wives. Both sets of responses in the following discussion have been merged to formulate a picture that reveals possible 'areas' that could to be woven into the fabric of strategies used to build distance education systems.

\section{The marriage/ family pattern}

As the nuclear family becomes a more predominant mode of family life in Mauritius, there will be a gradual shift in the role of the middle-class women from that of procreation, cooking, and conjugal services to that of companionship. As capitalist societies advance and strengthen, men as a collective group become more fragmented and less cohesive (Haralambos, 1984). Women's increased access to education that allows them to earn qualifications, as well as their social status within the family and society, enables them to interact with men (i.e., husbands) on more equal terms. Women are typically seen as more worthy of companionship in the eyes of their husbands, and thus were more likely to benefit from spousal support. Nonetheless, most husbands indicated that they were unwilling to sacrifice their comfort (strongly contributed to by the wives' presence), if their wives' educational endeavours did not ultimately yield extra personal satisfaction.

This study found that women from the upper middle-class typically had more supportive husbands than those women of the middle and lower-middle classes. This finding reveals that upper middle-class women benefit from a 'social space' wherein decision-making is shared and their status improved to the mutual societal and economic benefit of family (and community). There also seems to be a direct relationship between the wife's economic independence gained via employment (especially in the case of Indo Mauritian families) and the way she could negotiate familial relationships with her mother-in-law.

Although beyond the scope of this study, and in the absence of much needed empirical studies, anecdotal information indicates the Indo Mauritian mother-in-law still retains much of the behavioural traits of the legendary 'Indian mother-in-law' characterised by a stern and often intolerant attitude towards her young daughter-in-law. The culturally determined joint-family 
pattern reinforces this attitude. Recently, however, with more educated women in employment and the shift to the nuclear household pattern, the domineering position of the mother-in-law in the family is gradually being relinquished. Indo Mauritian households are thus gradually being transformed to that of a more democratic 'space' wherein wives and daughter-in-laws have greater say - a phenomena that is likely to strengthen and thus redress intra-family power imbalances in future generations.

\section{The occupational pattern}

Major hurdles remain in the expansion of the female workforce in Mauritius. Thus, women must personally negotiate their 'occupational social space' to accommodate formal on the job learning and training. Moreover, advances in technology will serve as a powerful tool to be used by women seeking to advance their education (and status). Greater skills and knowledge specialization will be needed by women to participate effectively in the rapidly emerging global information economy. Thus, women's educational opportunities must, by necessity, be reflective of and incorporate their occupational situation.

Access to education has allowed this study's subjects the opportunity and qualifications to climb the occupational ladder. To maintain and enhance their competitive edge, the women in this study indicated they are open to participating in 'lifelong learning' opportunities. Moreover, online education was seen as salvation by all women interviewed; they reported that online education enabled them to participate more effectively in society as a whole, whilst giving them the flexibility they need to accommodate their various roles and responsibilities in the 'marriage/ family' and 'occupation' social spaces.

In short, marriage/ family and occupation can be viewed as the 'social spaces' women use to shape their destinies - not the other way round. All couples interviewed were conscious that wives' participation in online education could lead to increased financial gain and economic stability for the family as a whole. Moreover, all the women interviewed (in varying degrees) stated they could count on their husbands for support in all spheres of their domestic life.

Nonetheless, this was not the case for women's occupational space. Indeed, these same women reported that while they felt had enough 'margin' to negotiate the time and space needed to engage in online distance learning, they still reported being cautious on how bring up the subject with their employer, irrespective of whether their superior was male or female. In other words, the women interviewed felt they did not have the same support from their employers (occupational space) as they did from their husbands (marriage/ family space). Nonetheless, these same women all agreed that online learning offered potential (i.e., democratize access) to education.

These women also acknowledged that participation in online education results in the least possible disruption to their family life. Indeed, most husbands interviewed voiced unstinting support to their wives; however, the subtext of their 'unstinting support' was found to be premised on the rewards that would accrue to the family unit as whole as premised on their wives' ability to upgrade their qualifications.

\section{Incorporating Online Distance Education}

The above indicates that online distance education is viewed by most participants in this study as an intelligent means of accessing education for women. Online education, due to its inherent flexibility, was also primarily viewed as an 'unobtrusive presence' that no other modality of 
distance education could provide. Among the Mauritian middle-class women interviewed, there were clearly strong opinions voiced in support of online education. It is hoped that the data presented here - albeit imperfect - will become self-explanatory over time with further research. Indeed, online distance learning is still not very familiar mode of education for this group of learners in Mauritius - women who need increased democratised access to lifelong learning opportunities if they are to benefit Mauritian society as a whole.

As plans for an open learning organisation move forward, the need for a niche market study to guide the organisation's development is clear. In concurring with Dirr (2003, p. 470) the researcher asserts that without a systematic empirical study examining the roles of learners (women, disabled, minorities, or otherwise), any distance education provision will built upon the uninformed assumptions of policy-makers and practitioners. Such uninformed assumptions, moreover, may in fact work against learners' real needs and aspirations. Despite politicians' noble intentions designed to increase access to education in Mauritius, without a clear understanding of who will comprise this institutions target learner groups, as well as an clear understanding of the underlying specificities of these target learner groups, real access could tacitly remain closed large sections of the Mauritanian population - in this case women. At policy level, the following points are therefore suggested, important points that the author believes articulates the needs of the women learners (as expressed in the data):

1. A systematic niche market survey should be undertaken to ensure policy makers and educational leaders in Mauritius responds to the real - not perceived - needs of learners (and by logic, national and personal development needs as well).

2. To counteract learner isolation, incentives should be provided for women learners to engage in distance education. Such incentives could range from study leave from work, provision of studygrants, and tax-rebates. While tax-rebates already exist in Mauritius, the amount allowed should be reviewed with intent of increasing a sustainable level of incentive for learners to register in distance education courses. Student aid should be proportional to the course load taken by students.

3. To promote student retention, the provision of training facilities for learners (i.e., computer training) dynamic and responsive student support systems will be needed (Miller, Rainer, and Corley, 2003).

4. Care should be taken to add a component of flexibility, whereby deadlines are negotiable and courses are not only cohort-based; such provisions encourage flexible entry.

5. Ensure access to all necessary components of the distance education program; that is access to teachers, peers, administrative and academic support, and students' ability to register at a distance and manage the aspects of their registration.

6. Special arrangements should be made for students to gain necessary accreditation and recognition with the Mauritius Qualifications Authority/Tertiary Education Commission (especially in cases where courses were completed elsewhere, such as an overseas university, for example).

7. Support mechanisms to accommodate students with disabilities should also be provided. As yet in Mauritius, there is no provision for support of students with disabilities. 
8. Development of a strong student feedback/ support infrastructure to aid learners studying online at a distance. This will involve budgeting for faculty training and investment in proper equipment and infrastructure.

9. Foster the concept of customer-centeredness at the open learning organisation, including the provision of incentives to the organisation to develop user-friendly packages aimed to support successful online learning.

10. To effectively redress the shortfall of learners as reported by the Mauritius Tertiary Education Commission (TEC, 1993), policies and legislation must be re-drafted to position 'distance education' as an attractive and viable option for learners in general, and women in particular. In the Mauritian context specifically, a social/ political infrastructure should be provided that supports the development of online learning at the open learning organisation. In addition, any such provision should benefit from a realistic budget to support it.

\section{Discussion}

To truly democratize access to education, women learners are encouraged to manage their time, exercise control over their own learning processes and goals, and to function effectively within the current constraints of their respective 'social spaces.' As elsewhere in the world, the development of women's self-motivation and self-directedness in any educational undertaking is important in Mauritius. Online education, more than any other type of educational modality, lends itself to a higher degree of learner control, and hence illustrates its potential to democratise access to education and thus improve the lot of Mauritian women, their families, and society as a whole.

\section{References}

Bullock, S. (1994). Women and Work. London: Zed Books.

Brockett, R. G., and Hiemstra, R. (1991). Self-Direction in Adult Learning: Perspectives on Theory, Research, and Practice. London and New York: Routledge. Retrieved on February 20, 2004 from: http://www-distance.syr.edu/sdlindex.html

Brown, A. (1997). Designing for Learning: What are the essential features of an effective online course? Australian Journal of Educational Technology, 13(2) 115 - 126.

Chang, W. L. (2003). The organisational innovation environment, self-directed learning, course design strategies, technology factors and the performance of Web-based training. International Journal of Organisational Behavior 6(4), 334 - 346. Retrieved February 23, 2004 from: http://www.usq.edu. /faculty/business/departments/hrm/HRMJournal/

Chant, S., and Mc Ilwaine, C. (1998). Three Generations, Two Genders - women and men in a changing society. London: Zed Books.

Dirr, P. J. (2003). Distance education policy issues: Towards 2010. In Moore, M. G. and Anderson, W.G. (Eds.) Handbook of Distance Education. (p. 461-479). New Jersey: Lawrence Erlbaum Associates, Inc.

Fonow, M. M., and Cook, J. A. (1991). (Eds.). Beyond Methodology - feminist scholarship as lived research. Indianapolis IN: Indiana University Press. 
Garrison, R.D. (2003). Self-directed learning and distance education. In Moore M. G. and Anderson W.G. (Eds.). Handbook of Distance Education. (p. 161-169). Mahwah NJ: Lawrence Erlbaum Associates.

Government of Mauritius (2004). Government of Mauritius Budget speech. Retrieved November 23, 2004 from: http://www.pwc.com/Extweb/service.nsf/docid/79EAF40D6E58EC3D85256EAE0020A9AB

Guba, E., and Lincoln, Y. (1983). Effective Evaluation. London: Fossey Bass Publishers

Haralambos, M., and Holborn, M. (1984). Sociology: themes and perspectives. (4th Ed.) London: Collins Educational.

Harding, S. (1987). Feminism and Methodology. Bloomington, IN.: Indiana University Press

Hartsock, N. (1990). Foucault on Power: A theory for women. In L. Nicholson (Ed.) Feminism/ post-modernism. London: Routledge.

Heward, C., and Bunwaree, S. (1999). Gender, Education and Development: Beyond access to empowerment. London: Zed Books

Henri, F. (1989). Towards New Horizons for Women in Distance Education: International perspectives. Journal of Distance Education. 14(1). Retrieved September 30, 2004 from: http://cade.athabascau.ca/vol4.1/12a_review-henri.html

Kemp W. C. (2002). Persistence of Adult Learners in Distance Education. The American Journal of Distance Education, 16(2). 65 - 81.

Kirkup, G., and von Prummer, C. (1990). Support and Connectedness: The needs of women distance education students. Journal of Distance Education 5(2) Retrieved September 30, 2004 from: http://cade.athabascau.ca/vol5.2/7 kirkup_and von_prummer.html

Kramarae, C. (2003). Gender Equity Online: When there is no door to knock on. In Moore, M. G. and Anderson, W.G. (Eds.) Handbook of Distance Education. (p. 261-272). Mahwah, NJ.: Lawrence Erlbaum Associates.

Liddle, J., and Joshi, R, (1986). Daughters of Independence: Gender, caste and class in India. London: Zed Books

Liddle, J., and Nakajima, S. (2002). Rising Suns, Rising Daughters: Gender, class and power in Japan. London: Zed Books

May S. (1994). Women's Experiences as Distance Learners: Access and Technology. Journal of Distance Education 19(1). Retrieved September 30, 2004 from: http://cade.athabascau.ca/vol9.1/may.html

Miller, M. D., Rainer, R. K., and Corley, J. K (2003).Predictors of Engagement and Participation in an On-Line Course . Online Journal of Distance Learning Administration, 4(1). Retrieved on July 19, 2004 from: http://www.westga.edu7Edistance/ojdla/spring61/spring61.htm 
Moore, M., and Kearsley, G. (1996). Distance Education: A systems view. Belmont, CA.: Wadsworth.

O’Connell, H. (1994). Women and the Family. London: Zed Books

Parsuramen, A. (1994). Ministerial Consultation on School Drop-out and Adolescent Pregnancy: The case of Mauritius. Port-Louis: Ministry of Education and Science.

Ramazanoglu C. (1993). Up against Foucault: Explorations of some tension between Foucault and feminism. London: Routledge

Rumble G. (2001). E-education: Whose benefits, whose costs? International Research Foundation for Open Learning. Retrieved on October 8, 2004 from:

http://www.iec.ac.uk/resources/e education costs.pdf

Spronk, B. (1996). Gender issues in distance education and training. Athabasca University Masters in Distance Education course module MMDE 651. Athabasca, Canada: Athabasca University Press

Stanworth, M. (1981). Gender and Schooling: a study of gender divisions in the classroom. London: Women's Researchers and Resources Centre.

TEC. (2003). Participation in Tertiary Education 2002. Mauritius: Tertiary Education Commission

UNESCO. (2001). Education for Peace, Human Rights and Democracy in the UNESCO Context. Retrieved October 17, 2005 from: www.unesco.org/education/uie/documentation/Democracy.pdf Universite Virtuelle: les premiers jalons. (2003, April 06). Week-end, p. A4.

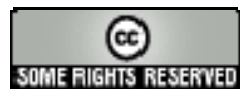

